УДК 821.161 .1

DOI: $10.17223 / 23062061 / 25 / 6$

\title{
Т.И. Рожкова
}

\section{СЮЖЕТ О КНИГЕ И ЧТЕНИИ В САТИРИЧЕСКИХ ЖУРНАЛАХ 1769-1774 ГГ.}

\begin{abstract}
Аннотация. Интерес современного гуманитарного знания к эпохе Просвещения как продолжающемуся до наших дней проекту делает актуальным изучение общественного диалога вокруг знаковых культурных практик. Материаль сатирической журналистики 60-70-х г2. XVIII в. позволяют заметить изменения в отношении к книге и чтению. На страницах журнальной периодики средневековая книга появляется в роли предмета межпоколенческой и мировоззренческой дифференциации. Новые читатели предпочитают литературу светского характера, практика «вчитывания» и толкования духовных текстов сменяется разносторонней начитанностью, опирающейся на свободу выбора, иироту интересов и критический характер мышления.
\end{abstract}

Ключевые слова: Просвещение, сатирическая журналистика, книга средневековая / светская, чтение, образование, культурные практики.

Общественная жизнь второй половины XVIII в. характеризуется многообразными аксиологическими сдвигами, определившими изменения общего облика культуры. Необходимость обсуждения проходящих процессов выразилась в стремительном оживлении периодической печати, появлении ряда журналов, воспринимающихся исследователями как единый комплекс, а потому названных «сатирическими». Характер публикаций, допускающих анонимность, многообразие вымышленных имен, памфлетность изображения, на столетия определил историко-литературный подход к их изучению. Потребность разобраться в причинах появления изданий, определить круг имен издателей, авторов и читателей связана с задачами всестороннего осмысления одного из ярких этапов национальной журналистики. Интерес современного гуманитарного знания к эпохе Просвещения как продолжающемуся до наших дней проекту делает периодику 60-70-х гг. XVIII в. источником наблюдений за сложными социокультурными процессами в обществе переходного характера [1]. Анализ изменений в содержании отдельных культурных практик, таких как книга и чтение, 
способствует пониманию внутреннего смысла перемен, механизмов преодоления противоречий времени.

Инициаторы публичного диалога не были профессиональными журналистами, но являлись сторонниками идей Просвещения. В публикуемых сочинениях больше репортерских черт, образующих живое впечатление реальности: «окинем глазами своими улицы», «зайдем хотя мимоходом... в домы». Рассказанные истории вдохновлены эмоциями наблюдателей: «расскажу частицу из моего похождения»; «есть у меня сосед»; «я был недавно в гостях»; «я недавно был в дружеской беседе»; «вчерашнего дня обедал я у некоторого человека» и пр. С этой точки зрения сложившийся сюжет о книге и чтении позволяет видеть время в контексте опыта его многочисленных рассказчиков. Появление новых черт в культурной практике чтения обнаруживается в высказываниях персонажей, попавших в поле зрения наблюдателя, в поступках, общих оценках происходящего. Знаковым образом журнальных листов видится «рассуждающий самодержавно» старик, настолько раздраженный временем, что когда с ним начинали говорить, «он тотчас закричит: Ты дружок еще молод, тебе надлежит передо мной молчать: может ли такой молокосос спорить с шестидесятилетним стариком?» (Смесь, 1769) [2. Л. 15. С. 116] $]^{1}$ Их, «престарелых и преданных самой древности», корреспонденты наблюдают в домах столичного и московского дворянства, где они - «недовольные», «соединясь за одно», - порицают время и молодых людей «нынешнего света», ведут разговоры об исправлении нравов, строят планы воспитания «строптивых... сыновей», размышляют, как «заградить... стези к развращению», как вернуть правила старинного поведения, «чему деды и отцы последовали» (Всякая всячина, 1769) [3. Л. 61. С. 161-162]. Так проблемы семейных и родственных отношений выходят за границы «домашних» споров, приобретают публичный характер и становятся характерной чертой времени [4].

Сюжет о книге и чтении появляется в материалах журналов закономерно. Книга как способ передачи Божественной мудрости, способ познания мира и воспитания человека и в Новое время остается принципиальной ценностью. Она продолжает выполнять возложенные

\footnotetext{
1 Для понимания включенности журналов в общий диалог ссылки на отдельные издания даются в тексте статьи дополнительно, с указанием года публикации.
} 
на нее функции: «даровать свет умственный», «поучать истинам и добру», «образовывать ум и сердце». Предшественник эпохи писатель и богослов Симеон Полоцкий так представлял диалог человека и духовного текста:

Ходяй при водах, всяко омочиться, приседяй огню, тепла исполнится. Такочитаяй книги божественны аки по нужде будет умудренны.

$$
\text { (Чтение, 1678) [5. С. 165]. }
$$

Строки его стихотворения хорошо иллюстрируют практику средневекового чтения, для которого, как писал Ю.М. Лотман, важно «не количественное накопление прочитанных текстов, а углубление в один, многократное и повторное его переживание. Именно таким путем совершается восхождение от части (текста) к целому (истине)» [6]. В Новое время существенную трансформацию переживали участники диалога: читатель и книга.

C 60-х гг. XVII в., по наблюдениям А.С. Демина, у российских читателей появилось «отчужденное отношение» к средневековой книге, «сродни смутному недовольствию, холодности, может быть, скептичности» [7. С. 181]. Петровские преобразования привели к дальнейшим сдвигам в репертуаре книг «человека читающего». По выводам Л.А. Черной, в годы правления Петра I «рациональный пласт восприятия действительности расширился настолько, что не просто потеснил и сузил пласт религиозного сверхчувственного мировосприятия, а проник в него и насытил собою» [8. С. 77]. Петр Великий подчинил рациональному началу вопросы иррациональной религиозной сферы ${ }^{1}$. Он выработал «механизмы освоения новой культуры в разных социальных слоях», в числе этих механизмов - система образования и книжное дело [Там же. С. 78].

Не останавливаясь на проблеме авторства размещенных в журналах материалов, на оценках степени включенности каждого издания в общий диалог, проследим, как изменилась личность читателя, что говорили о книге и чтении на страницах сатирических журналов.

1 Л.А. Черная приводит документы эпохи, иллюстрирующие рациональную позицию Петра I. В них он указывает церковнослужителям провести проверку подлинности жития святых, знамений и чудес [Там же]. 
Выбранный аспект исследования дает возможность дополнить описание социально-организующей функции культуры в эпоху Просвещения.

В критическом дискурсе времени легко заметить персонажи, доставшиеся с петровских времен. Их поведение противоречит логике жизни. В обществе растет престиж интеллектуальных занятий, а купец, мечтающий о дворянстве, «не наполняет своей головы разумом», презирает науки, а чтение светских книг «почитает за грех». Государство ищет пути «смягчения нравов» подчинения, а он без страха и совести обогащается «от разорения народного» (Трутень, 1769) [9. Л. 24. С. 187].

В стенах своего дома замкнулся осторожный дворянин. Страх новизны отвратил его от книг, он ничего не читает и живет наставлениями тетушки, которая говорила, что «в светских книгах много ереси» (Трутень, 1769) [Там же. Л. 31. С. 246-247]. Исключение сделал для сонника, по его «толкованиям» «располагает» день, год и жизнь.

Безрассуд, житель Москвы, тоже воспитывался «под присмотром старушки», от нее усвоил «простонародные басни о сотворении мира» (Трутень, 1769) [Там же. Л. 18. С. 139]. С этим знанием принялся читать книгу Фонтенеля «Разговоры о множестве миров». Попытка понять знаковую книгу эпохи закончилась для него трагически ${ }^{1}$. Новый взгляд науки на механику движения небесных тел, где Солнце стоит, Земля ходит, огромные «висячие» тела вращаются один вокруг другого и пр., поразил его. Безрассуд закрылся в комнатах, перестал пить и есть; пришла мысль о смерти и наказании ${ }^{2}$.

Потенциальные читатели, воспитанные «тетушками» и «старушками», по-прежнему дистанцировались от европейского влияния, светская книга оставалась для них чужой и болезненно пугающей.

Значительно оптимистичней судьба светской книги выглядит в контексте обсуждения в обществе проблем воспитания. В этом пространстве она находит неоценимых сторонников. В литературной ми-

${ }^{1}$ О распространении астрономического знания и его влиянии на русскую культуpy XVIII в. см.: [10].

${ }^{2}$ Н.П. Черепнин, представитель петербургской исторической школы, опираясь в том числе на материалы журналистики, писал: «В редком доме можно было найти какуюнибудь книгу, и то преимущественно духовного содержания или сонник и гадательные книги. Большинство дворян ничего не читало; иные думали даже, что слишком прилежное чтение книг, в том числе и Библии, сводит человека с ума» [11. С. 14]. 
стификации, безусловно, вдохновленной реальностью, в знаменитых письмах дяди к племяннику журнала Н.И. Новикова «Трутень» (1769) книга становится знаком культурной границы, по одну сторону которой изображается дядя, требующий от племянника послушания и соблюдения интересов семьи, по другую - Иван, отъехавший в столицу для определения на службу (придворная, военная, приказная).

Поведение племянника тревожит умудренного летами и богатым жизненным опытом родственника. Иван «оставил» чтение священных текстов, «увеселяющих чистые сердца и дух сокрушенный услаждающих» [9. Л. 15. С. 115]. В столице общается с учеными людьми, много читает, изучает иностранные языки. Для опекуна молодого человека последствия предсказуемы: «от тех книг погибнешь ты невозвратно»; «читая такие книги, стремитеся вы... ко дну адскому на лютые и вечные мучения» [Там же. С. 119]. Доискиваясь до причин разлада, он размышляет о воспитании.

Старшего племянника семья отдала в престижное и многообещающее учебное заведение - Сухопутный кадетский корпус, где встраивалась идея Екатерины II о воспитании «новой породы людей» «свободной от пороков прежнего общества» [12]. И.И. Бецкой, советник императрицы по вопросам образования, видел воплощение проекта в жизнь в «строжайшей изоляции кадет от родителей», от дурного влияния семьи [13. С. 47]. Пребывание старшего наследника в закрытом учебном заведении сделало его чужим для «наживной» науки дяди, а отцу принесло «разорение и печали» [9. Л. 15. С. 114]. Чтобы не было «недосмотра» в образовании младшего, его до 20 лет воспитывали дома. Рос юноша на чтении «жития святых отец» и Библии. К 16 годам отлично знал акафисты, каноны, молитвы, «круг церковного служения» и мог самостоятельно «отправлять» службу. Как заметил дядя, Иван «соответствовал» стараниям покойного отца и заслужил уважение стариков и духовных лиц. Интерес племянника к «пагубным» книгам, «развращающим разум», наполненным «богопротивным умствованием», «расколами противу закона» проявился для дяди неожиданно. И если утрату родственных и духовных привязанностей брата Ивана можно объяснить пребыванием в закрытом учебном заведении, то младший сделал выбор самостоятельно.

В непочтении к старой книге, удерживающей традиции семьи, заподозрил сына Трифон Панкратьевич, «заслуженный и почтенный 
драгунский ротмистр». Он предостерегает Фалалея от чтения распространенных в столице «печатных листочков», предполагая в сочинителе «какого-нибудь немца», и напоминает ему мудрость старорусских книг. В наставлении Трифон Панкратьевич особо оговаривает ценность подаренных сыну святцев: «...не потерял ли ты святцев, которыми я тебя благословил. Береги их; вить это не шутка» (Живописец, 1772) [14. Ч. 1. С. 56]. В свое время книгой благословил Трифона Панкратьевича отец («покойник дедушка»), а того - духовный отец «ильинский батюшка». По семейным рассказам, «Святцы» помогли деду избавиться от болезни: «Он был болен черною немочью и по обещанию ездил в Киев: его Бог помиловал, и киевские чудотворцы помогли» [Там же].

Фалалей - третье поколение в ряду наследников священного текста. Для него отцовское благословение и наставление утратило полноту сакрального смысла. В контексте жизненной практики сына рассуждения отца противоречат наблюдаемым фактам времени. «Кормчая книга», пишет Трифон Панкратьевич, запрещает знакомство с иноземцами и полагает «за это проклятие» [Там же. С. 57]. Помещиков нельзя называть «тиранами», как их называют в сатирических листах, привезенных соседом Брюжжаловым, так как в «Четьях-минеях» тираны - «нехристи», что мучают святых, а «мужики вить не святые» [Там же. С. 58]. Обилие наставительных цитат из книг «душевнополезного» чтения говорит о привязанности старшего поколения к духовным текстам: на них они выросли, а теперь воспитывают своих детей.

Публикации в журналах Н.И. Новикова, где показано явное расхождение читательских интересов близких поколений, не были исключительными. В материалах «Всякой всячины» (1769) высмеиваются старики, «преданные самой древности». На выход в свет новых еженедельных листов они реагируют «ворчанием». По их мнению, лучше, «если б издали в печать разные духовные душеполезные книги» [3. Л. 61. С. 161]. В журнале «Смесь» (1769) описан «некий знакомый», который «все древние мнения принимает за святые, хотя бы они были и совсем опровержены. По такому его предрассуждению, чем старее сочинение, тем оно почтеннее, справедливее и основательнее» [2. Л. 15. С. 113].

В поведении нового поколения дворян проявляются решительный и самостоятельный интерес к чтению книг философского и научного 
содержания и недоверие к наставительным речам старших. Их стремление найти ответ на вопрос - «как и из чего создан мир» в логике жизни старших воспринимается как бесполезное и «благопротивное умствование», ибо «судьбы божии неиспытанны» [10. Л. 15. С. 118].

Преподаватели Сухопутного кадетского корпуса были готовы поддержать своих воспитанников, публикуя на страницах журнала «Полезное с приятным» (1769) нравоучительные переводы. В выборе материала они ориентировались на английскую юношескую книгу [15].

В статье «О притворстве» кадеты предостерегались в отношении тех людей, «кто наружно принимает на себя такой нрав, коего он в самом деле не имеет» [16. Седьмой полумесяц. С. 2]. Тема продолжается в публикации «Сон», взятой из книги, «называемой “Улей"». «Сердца человеческие наполнены обманом, ложью и притворством», декларируют авторы. Дворянин, вступающий в жизнь, должен понимать, что «из разговоров и внешнего вида не можно о человеке заключить, что он есть на самом деле» [Там же. С. 8]. В этом же году «Трутень» (1769) размещает портрет Простосерда - человека «слепой доверенности». Он «всем верит и думает, что люди не могут быть злыми за тем, что добрыми сотворены» [9. Л. 24. С. 185]. Глобальную задачу разоблачения лжи ставит автор письма в журнал «Живописец» (1772): «...время уже в просвещенный век наш снимать личину с порочных людей и представлять их свету таковыми, каковы они в самом существе суть» [17. Л. 17. С. 129].

К изображению противоречивости человеческой натуры, конфликта противоположных начал его души русские книжники подошли в позднее Средневековье. По мысли Д.С. Лихачева, «обнаружение сложности человеческого характера, открытие в нем соединения злых и добрых черт вели к гибели средневековой идеализации» [18. С. 105]. Журналистика 1769-1774 гг. с ее критическим взглядом на мир подвергла сомнению искренность диалога старших современников с Богом, обнаружив в их поведении философию необязательности исполнения Божьих заповедей. Дядя, поучающий ослушавшегося племянника Ивана, признается в своей греховной жизни: «Я сам, грешник, ведаю, что беззакония мои превзыдоша главу мою; знаю, что я преступник законов, что окрадывал государя, разорял ближнего, утеснял сирого, 
вдовицу и всех бедных судил по мзде» (Трутень, 1769) [9. Л. 15. С. 115]. Он понимает масштаб своего отступничества: «грешил почти противу всех заповедей, данных... через пророка Моисея, и противу гражданских законов» [Там же]. При этом уверенно оправдывается перед племянником исполнением других христианских обязанностей: раз по пять с «сокрушенным сердцем» служит службу, не просто соблюдает посты, а «еще прибавил», домочадцев к тому «принуждает».

Трифон Панкратьевич, наставляющий сына фразами из духовных сочинений, в реальной жизни далек от христианской морали: ему хочется «у соседа... земли отнять», «деньги отдавать в проценты», взятки брать (Живописец, 1772) [14. Ч. 1. С. 57]. Вместо того, чтобы проявить к крестьянам человеколюбие, предпочитает их сечь: «Секу их нещадно, а все прибыли нет», «на что они и крестьяне: его такое дело, что работай без отдыху» [Там же. С. 58]. В семье Трифона Панкратьевича давно освоили альтернативный путь спасения души и обеспокоены только повышением стоимости грехов: «грешки дорогоньки» становятся, «молитва до Бога доходна, да убыточна» [Там же. С. 56]. Во взглядах бывшего драгунского ротмистра не оказалось понятия дворянской чести («За честью, свет, не угоняешься...»), чувства долга перед государством и престолом. По своему опыту понимая, что время неспокойное и военная служба грозит сыну увечьями, он советует взять отставку, вернуться домой, есть «досыта» и спать «сколько хочешь» [Там же. С. 60].

На несоответствии правилам христианского поведения выстроен у Н.И. Новикова портрет ханжи. Сочинитель наблюдает своего героя, «смиренно» выходящим из церкви, где он «раздает по полушечки бедным», «идучи читает молитвы...» Внешняя картина оказывается лживой: «Ханжа грешит поминутно, но показывает себя праведником, идущим по пути, устланному тернием. Притворные молитвы, набожность и посты не мешают ему разорять и утеснять сколько можно подобных себе. Ханжа грабил тысячами, а раздает полушками» (Трутень, 1769) [9. Л. 28. С. 223]. Заключительные строки портрета прямо обращены к разуму молодого поколения: «Такою наружностию он многих обманывает. Молодым людям ежечасно толкует девять блаженств, но сам в шестьдесят лет своей жизни ни единажды ни которого не успел сделать» [Там же]. 
Ложных праведников обличает журнал «Смесь» (1769). «Набожный» герой, появившийся на его страницах, «каждый день по три раза ходит в церковь, стоит в ней смиренно и думает, что своим богослужением заменяет все добродетели и может, забыв честь и совесть, вдаваться во все пороки» [2. Л. 10. С. 75].

Изображая ханжество в вопросах веры, издатели продвигали идею ценности европейской книги и нового типа знаний в воспитательном процессе. Материалы предлагали задуматься, насколько включенность человека в обрядовую жизнь церкви способствовала пониманию смыслов религиозной практики, определяла внутренний мир соотечественника, принципы гуманного отношения к «другому», в частности к крепостному крестьянину. Ярким примером отсутствия прямой связи становится домашняя жизнь Трифона Панкратьевича, готового «закуралесить» в любую минуту, да так, что «святых вон понеси». Публикации открывали дорогу педагогическим экспериментам времени, где появлялся круг литературы «просветительского жизнестроительства» (выражение Н.Т. Пахсарьян [10]).

Мысль о том, что вера и ученость должны не противоречить друг другу, но гармонично сочетаться, изложена в письме господина Р..., опубликованном в «Живописце» (1772). Размышления поданы в жанре сна. Отдельные фрагменты высказывания Р... сливаются с общим хором хвалебных слов в адрес реформ дворянского образования: «Благополучна та страна, где юношество к пользе государя, ко благосостоянию общества, ко преодолению господствующих в народе предрассуждений и к собственному своему благополучию хорошо воспитывается» [14. Ч. 2. С. 121]. Р... пугает влияние новых «мудрецов», приводящее к сомнению «бытия Божия». В обществе он наблюдает людей, «не особенно вдумчивых и склонных к заблуждению», что, наслушавшись чужих рассуждений, «возвращаются домой с сердцами гордыми, памятозлобными; и равномерно как на друзей, так и на недругов своих неугасимою ненавистью пылающими» [Там же. C. 122]. «Незнакомец» задается вопросом: «Неужели и во всех государствах такие произрастают от наук плоды?». Стараясь повернуть мысль читателей к вопросам веры, он отвечает на него сам: «Науки приносят обществу великие пользы и связывают его самыми крепкими узами здравого рассудка: они учат жить добродетельно и Богу должное воздавать почтение» [Там же]. «Безумие» отрицания, считает 
Р..., «ничем другим предупредить не можно, как только частым напоминанием молодым людям того, что кто Бога забывает, тот верно навлекает на себя праведный его гнев» [14. Ч. 2. С. 122] ${ }^{1}$.

Внимание Екатерины II к вопросам формы (государственное, частное, домашнее) и содержания (круг учебных дисциплин) образования дополнительно мотивировало дворянство соответствовать духу времени. В журнале преподавателей Сухопутного кадетского корпуса в статье «О воспитании» замечено: «...родители должны паче всего стараться о благом направлении сердца и просвещении ума детей своих» (Полезное с приятным, 1769) [16. Первый полумесяц. С. 7]. Новые культурные установки заставляли дворянство реагировать на необходимость обучать детей основам рационального знания.

Реальные истории родительского «попечения» выглядят в журналах значительно сложнее. Из соображений осторожности, недоверия, а также нерешенности вопросов финансирования светское образование оставалось для дворянской семьи непростым делом [21. С. 278279]. Одну такую историю размещает журнал «Полезное с приятным» (1769). Фома Стародуров - человек богатый и деньгами, и связями; грамоте выучился поздно. В 25 лет «зачал... учиться российской азбуке», т.е. тогда, когда Петр Великий «дворян велел выгонять в службу». К тому времени, как подросли внуки, он понимает, что «без наукто немного получишь», но современные условия кажутся ему «очень чудными» и «денежки таскающими». Фома боится отправить внучат в столичную школу, ибо уверен, что там они непременно научатся «от иноземцев... отступничеству», привыкнут «по постам есть мясо» [16. Второй полумесяц. С. 24]. Приняв решение учить наследников дома, он скупится на учителей, «жалеет употребить пристойную... сумму», в то время как «на удержание аршина земли тратит сотни,

\footnotetext{
${ }^{1}$ Нужно заметить, что прямая сатира на служителей церкви в журналах почти отсутствует. Несколько сатирических зарисовок больше дополняют общую картину «неблагополучия» нравов. «Адская почта» (1769) знакомит с настоятелем, сочетающим пьянство с крайней набожностью: «Не могши владеть ни руками, ни ногами, сказал своему слуге: “Перекрести ж меня, хлопче”. Не успел хлопец его перекрестить, то он, дремя, приказал ему, чтоб у его постели прочел вместо него вечерние молитвы, что было и сделано» [19. С. 24]. Приходской пономарь в журнале «И то и се» (1769), наевшись в постный день говядины, «пляшет по гудку в присядку» [20. 29 неделя].
} 
забывая закон, совесть, благопристойность и честь» [16. Второй полумесяц. С. 28]. Публикацией сюжета о Фоме Стародурове издатели хотели решить несколько задач, о чем сообщают в комментарии. С одной стороны, надо научить общество смотреть на таких родителей, «как на недостойных» [Там же. С. 27]. С другой - необходимо поддержать тех, кто «для просвещения детей своих ничего не жалеет и оному многим жертвуют» [Там же]. Такие дворяне - «истинные сыны отечества, старающиеся о возвышении оного и употребляющие имение свое на дела полезные и богоугодные» [Там же].

Недальновидные взрослые часто становятся причиной жизненных неудач своих детей, не понимают или неверно оценивают потенциал их молодости, перспективы светского образования. В журнале «И то и се» (1769) рассказывается о судьбе юноши, «от природы острого понятия» и весьма любопытного. Грамоте он выучился дома, затем начал вдумчивое чтение духовных книг. «Вдумчивое» чтение предполагало письменную проработку текста. То, «что ему казалось достойно примечания, выписывал... на бумажку», затем, «в свободное время, вытверживал наизусть» [20. 2 неделя]. Пытливый ум жаждал дальнейшего образования. Просьба нанять учителя вызвала гнев и «досаду» отца. Молодой человек был наказан «ременной плетью», вынужден бежать из дома.

Примером суеверного «безрассудства» родителей служит история юноши из купеческой семьи. Имея возможность и желание дать сыну образование, родители вместо того, чтобы приставить к нему «умелых» учителей, «принялись ездить по разным церквам», заказывать молебны и просить угодников «открыть сыну их российскую грамоту» (И то и се, 1769) [Там же. 42 неделя].

В журнале «Смесь» (1769) корреспондент сообщает о состоятельном соседе, что деньги дает в рост, строго наблюдает молитвенные часы. Однако воспитанием детей пренебрегает: «...они и поныне русской еще грамоте не знают, хотя и младшему минуло восемь лет. Он говорит, что хорошего учителя не может найти, а плохому поручить не хочет, а дети между тем балуются, хотя все они могли бы быть отечеству полезными» [2. Л. 17. С. 141].

Н.И. Новиков также «полагал, что важной составляющей процесса формирования нового человека должен быть пример родителей и их непосредственное участие в образовательном и воспитательном про- 
цессе» [22. С. 690]. Исповедальный сюжет этой темы мы находим на страницах журнала «Живописец» (1772). Некий $\mathrm{E}^{* * *}$ присылает свою историю, которую назвал «Следствия худого воспитания». В сопроводительном письме к публикации и в примечании издатель отмечает адресованность материала родителям, желание вызвать у них «старания» при воспитании детей: «Отцы и матери! Казнитеся сим примером; воспитывайте детей своих со тщанием, если не хотите опосле быть ими презираемы» [14. Ч. 2. С. 158].

Причиной «несносных бедствий» Е*** считает необдуманное воспитание. Отец жил так, как жили предки: «сообразовывался со всеми древними обычаями», «понемногу» разбирал «Четьи Минеи» и другие церковные книги. Он обучил сына началам российской грамоты. Мать была занята чтением модных французских романов. Е*** рос в несогласии родителей, «в праздности и лени», пристрастился к пьянству, карточным играм [Там же. С. 157]. Устроить жизнь, пишет он в своей записке, помогли нужда, военная служба, оставшиеся искры «стыда и совести». $\mathrm{E}^{* * *}$ признается, что опубликовать свою историю его заставило «сожаление об участи тех бедных», которые получили подобное воспитание [Там же. С. 158].

В истории дворянского рода из Коширы прослеживается разрушение идеи службы государю. Прадед участвовал в военных «походах», вернувшись, построил в родовом селе церковь. Строительство могло быть знаком благодарности Богу за дарованную жизнь. Дед получил возможность «наскоро» построить семейный дом, что позволяет предполагать его постоянную служебную занятость. Сын и внук «отягощены делами» иного толка. Сын - «пил, ел и спал» (Трутень, 1769) [9. Л. 16. С. 124]. Внук - «упражнялся в весьма полезных делах для пользы земных обитателей» [Там же]. Ирония выражения - «полезные дела для пользы земных обитателей» - становится понятной в контексте складывающейся культуры «просвещенного взгляда на мир» [23]. К 70-м гг. XVIII в. в круг повседневных дел «просвещенного» человека входили обустройство имения, строительство усадебных комплексов, включающих театры и оранжереи? обустройство кабинетов для проведения интеллектуального досуга, воспитание детей, занятие словесностью [Там же]. «Полезные» дела дворянина из Коширы свелись к содержанию бойцовых гусей, петухов, охотничьих собак. С ними, на старинной дедовской карете, в сопровождении шутов и ду- 
раков, он выезжал на ежегодные ярмарки. Проживая нажитое предками имение, он даже не задумывался над судьбой своего пятнадцатилетнего сына. Воспитание поручил «дьячку... прихода» под тем предлогом, что «разумнее» его никто из семьи уже не будет.

Реальность, какой ее представляют журналы, говорит о серьезном разрушении понимания между близкими поколениями: отцами и сыновьями. В условиях финансовой зависимости наследников такие отношения обещали серьезные внутрисемейные конфликты. Дядя, уговаривая племянника Ивана оставить «пагубные книги» и вступить в приказную службу, угрожает ему потерей наследства («ежели хочешь быть моим наследником, то исполни мое желание»), но в случае возвращения обещает выгоды и покровительство («жалованье вполдесяток в год получишь»). Трифон Панкратьевич готов высечь Фалалея кнутом «за непочтение», грозит убить «до смерти», не страшась «церковного покаяния» [14. Ч. 1. С. 60]. И если бежавший «от ременного» наказания молодой юноша «стал разумен», то другие герои повествований, такие как $\mathrm{E}^{* * *}$ и Добромысл, едва устояли перед искушениями жизни. Как заметила А. Бекасова, проанализировав взаимоотношения отцов и детей в последнюю треть XVIII в., «чтобы стать полноправным наследником», «иметь свое независимое мнение», «сыновьям следовало не только быть преданными и научиться подчиняться. Они должны были овладеть искусством общения, поддерживая связи и взаимовыгодные отношения как с ближайшими родственниками, так и с гораздо более широким кругом людей, неутомимо добиваясь расположения, благосклонности и доверия окружающих. Наиболее успешным оказывался тот, кто умел договариваться, идти на компромиссы, отстаивать семейную репутацию, пользуясь для этого соответствующим языком политической коммуникации» [4].

Круг размещенных в журналах историй стремился убедить читательскую аудиторию в пользе образования, разума, «просвещенного науками»: «его ни промотать, ни проиграть не можно», «он богатство нашей жизни, он украшение человеческое, он утешение в наших печалях» (И то и се) [20. 33 неделя]. Особое место в разработке этой темы занимает сюжет о новгородском дворянине Добронраве, где представлена идеальная семья и конструируется идеальное решение проблемы (Пустомеля, 1770). Живущий в своем имении Добронрав не отличался рвением к наукам, что ставит его в один ряд с другими 
обыкновенными провинциальными дворянами и родителями, каких много. Его главное достоинство в способности понимать время и потребности своего сына. Он человек «добросердечный», щедрый («славится хлебосольством»), милостивый. Сердечность и «благоразумие» помогли определиться в вопросах воспитания. Добронрав развивает природные дарования сына, выписывает из Петербурга достойных учителей, «известных разумом, учением и добропорядочным поведением» [24. С. 171]. При отсутствии института гувернерства решение этого вопроса было делом непростым [25. С. 32]. С помощью наставников Добросерд изучает три иностранных языка, читает «славных авторов», формирует для себя «истинное о вещах понятие». Набор учебных дисциплин Добросерда сопоставим с предметами кадетского корпуса: логика, физика, математика, география; российская история («знал сокращенно деяния наших предков»). Они направлены на формирование логики рационального мышления, основ точного знания.

Финал истории выстраивается так, чтобы показать, как оправдываются родительские усилия. В столице молодой человек сдает экзамен на офицерский чин, в отношениях с другими дворянами умеет отличить искренность от «лживого притворства», подготовлен к восприятию театральных постановок - главного и модного развлечения молодежи времени Екатерины II. Добросерд не следует «примеру молодых людей, которые в театр за тем только ходят, чтобы посмеяться; но рассматривая с прилежанием, нужное замечает и по выходе исследует сам себя как строгий судья, не имеет ли какой слабости, которые того дня публично были осмеяны» [24. С. 173]. «Историческое приключение» - именно так названа эта история, потому «историческое», что в нем представлены преимущества нового диалога с миром. У Добросерда сформировано чувство дворянского долга перед Отечеством. Получив ордер явиться в полк, выступающий «против неприятеля», он тотчас отправляется на службу, «наполняя сердце свое храбростию и желанием себя прославить», несмотря на то, что к этому времени был помолвлен и ожидал свадьбы [Там же. С. 176].

Если Добросерд после сдачи экзамена «пожалован чином», то офицер Худовоспитанник («ничему не учился, ничего не читал и ничего не знает»), маскирующий собственное невежество претензиями к наукам («науки и книги умягчают сердца; а от мягкосердечия до трусости 
один только шаг»), отправлен правительством в отставку с выплатой денег вместо чина (Живописец 1772) [14. Ч. 1. С. 34].

Престиж всесторонних и глубоких светских знаний представлен читателям в IV листе «Трутня» (1769). На место с приличным и «безгрешным» доходом Н.И. Новиков сталкивает трех претендентов. Первый - «дворянин без разума, без науки, без добродетели и без воспитания». У него одно достоинство - он «родня многим знатным боярям» [9. Л. 4. С. 29]. Второй - тоже дворянин: «Поведения доброго, разума хотя не пылкого, однако наукою подкрепленного» [Там же]. Качества третьего соискателя описаны с особыми подробностями. Проситель не дворянин, но «от добродетельных и честных родился мещан». Его природный разум «укреплен» учением в России и чужих краях: «...мало таких наук, которых бы он не знал или о которых бы он не имел понятия» [Там же. С. 30-31]. Журнал оставляет решение задачи открытым, но для большинства читателей понятно - меньше всего шансов у первого претендента.

Тему продолжает история Добромысла журнала «Вечера» (1772). К пятнадцати годам юноша остался сиротой, наследником «великого имения», но не был готов к самостоятельной жизни, «не знал искусства познавать людей» [26. Ч. 1. С. 145]. Тетушка перевезла его в столицу, где он «прельстился» светской жизнью. «Старинный друг» семьи помог исправить ситуацию. И когда Добромысл вышел в отставку и вернулся в имение, он не только «упражнялся в домостроительстве, делал крестьян своих счастливыми», но со всей серьезностью подошел к воспитанию детей: «воспитывал... с рачением; влагал в сердца их семена добродетели, не скрывал от них слабостей и пороков людских; и наконец, твердил им непрестанно: познавайте себя и тех, с кем вы знакомство начинаете, и будете счастливы» [Там же. С. 148].

Несмотря на то, что журналы фиксируют устойчивость негативного взгляда на европейскую культуру, выросло поколение, сопричастное идеям Просвещения. Церковная книга в их сознании перестала быть единственным наставником. На страницах сатирических журнальных листов она оказалась связанной с изображением человека прошлого, неспособного понять и принять новые смыслы жизни.

Изучение чтения как культурной практики обрело свою актуальность в последние десятилетия XX в. в связи с потребностью написать историю литературного процесса со стороны читателя. Стати- 
стическому анализу читательской аудитории России в 1762-1800 гг. посвящены работы А.Ю. Самарина [27]. Французский исследователь Р. Шартье обратил внимание на то, что в Европе во второй половине XVIII в. стали читать не просто больше, но и по-другому. По его наблюдениям, с увеличением числа издаваемых книг читатель утрачивает привычку «прилежно, внимательно и терпеливо читать». Его отношение к книге приобретает «свободу», «непринужденность», «критичный» характер [28. С. 102]. По мысли Ю.М. Лотмана, читатель Нового времени по-новому, в сравнении с предшествующим временем, сформулировал для себя движение к истине. Теперь он понимал этот процесс «как количественное увеличение знаний, суммирование прочитанных книг, поскольку путь к целому - подлинному знанию - лежит через соединение частей. С этой точки зрения ближе к мудрости тот, кто больше прочел книг» [6].

Поколение, выпавшее из старорусской традиции «вчитывания» и толкования духовных текстов, с приходом светской книги получило возможность знакомства с текстами разных культур по разным направлениям наук и искусств. Ему приходилось приспосабливаться и вырабатывать более динамичный диалог с растущим книжным рынком. Наблюдать эти изменения, находясь внутри процесса, корреспондентам было непросто, поскольку здесь начинались «непредсказуемые эффекты» Просвещения. Автор письма в журнал «Всякая всячина» просит редакцию напомнить молодежи, чтобы «читали славных оных во древности писателей не мельком или бегом, как обыкновенно читают часовник или псалтырь спешащие дьячки, не понимая в них и десятого слова, но обращали бы их чтение» «в сок и в кровь к себе» (Всякая всячина, 1769) [3. Л. 110. С. 290] ${ }^{1}$. Представляя своих читателей, Н.И. Новиков использует говорящие имена: Славен, Зрелум, Несмысл, Безрассуд и пр. Славен, мнением которого он особо дорожит, читает «между важными делами», Высокопар - не читает, но «хулит», Вертопрах читает листы, но находит в них только «забаву», Роза «читает и не понимает», Нарциса «рассуждать о них не имеет времени», Зараза читает, «танцуя» и пр. [9. Л. 35. С. 273]. Подмечен-

${ }^{1}$ В этом же году М.М. Херасков печатает нравоучительную оду «Чтение», где высказана похожая мысль: «О вы, которые хотите/ Читаньем просвещать умы! / Без пользы многих книг не чтите,/ Остерегайтесь пущей тьмы [29. С. 389]. 
ные привычки чтения, хорошо иллюстрируют другое наблюдение Р. Шартье, связанное с утратой одного из базовых качеств древнейшего способа передачи знаний: «На смену всеобщему почтению к книге, проявляющемуся в уважении и безграничном доверии, приходит более свободное, более непринужденное отношение к печатному слову» [28. С. 102-103]. С разрушением представления о книге как Божественном вдохновении, с расширением мирских (познавательных, развлекательных и пр.) смыслов книга утрачивает свой авторитет, а чтение - сакральный характер.

На страницах журнала Н.И. Новикова одна из наследниц богатой библиотеки отца, признается: «...я ни одной не беру в руки. <...> Все Феофаны да Кантемиры, Телемаки, Роллены, летописцы и всякий этакий вздор. Честью клянусь, что я, читая их, ни слова не разумела» (Трутень, 1770) [9. Л. 6. С. 41]. Не всякий читатель времени Просвещения, оставив духовные тексты, обратился к «славным» авторам прошлого или современности. Читателям открылась привлекательность «недолговечных текстов», текстов досуга, развлекательной литературы. На это обратил внимание издатель журнала «Адская почта»: «Где недавно до небес возносили книгу Б***, там ныне оной предпочитают $\mathrm{K}^{* * *}$, которую книгу, если бы к нам возвратясь Сократ или Цицерон прочли, назвали бы ее двоюродною сестрою Бовы Королевича. <..> все сего героя дела похожи на такие сказки, как Бова Королевич, Петр златых ключей и проч.» [19. С. 197]. Не только интеллектуалы, но и модники света расставили книги в своих кабинетах. В одной из публикаций «Адской почты» художник вынужден заметить заносчивому автору: «...Признайтесь, г. Сочинитель... многие и ваши книги для украшения своих библиотек, так как и наши картины для украшения покоев покупают» [19. С. 214]. В библиотеке Скудоума книги содержатся «в шкапах красного дерева», но стекла у шкафов разбиты, а «от частого чтения моль половину их переела, а остатки покрыты пылью» (Трутень, 1769) [9. Л. 26. С. 202].

Идея воспитания «новой породы людей», сложившаяся к 1766 г., коснулась каждой дворянской семьи. Она вызвала необходимость корректировки ценностных ориентиров, основанных на книге русского Средневековья. На какой-то период преемственность культурных связей между поколениями стала проблемой. Традиционные наставники (тетушки, отцы, старушки, приходские священники), обучая детей азам 
грамотности и мудрости по средневековым книгам, в основной своей массе не были готовы стать проводниками идеологии Просвещения.

Запрос государства на «просвещенность» потеснил духовную книгу в учебных аудиториях, в практике частного чтения, в личных библиотеках. Неслучайно, просматривая библиотеку местного прокурора, дядя Ивана не нашел, где посмотреть, «какого святого в тот день празднуется память», но встретил повесть Вольтера «Кандид». Для вступающего в жизнь молодого человека светская книга выходит на первый план в случае необходимой репрезентации себя как просвещенного дворянина.

Периодические издания 1769-1774 гг. включились в обсуждение новых идей, предложенных временем и Екатериной II. В письмах читателей, услышанных и увиденных историях, литературных сочинениях мы наблюдаем не только критический настрой мысли, но и примеры возможного и даже идеального решения очевидных проблем, где светское образование и светская книга определяли успех при дворе и в обществе. На страницах журналов конструировался идеализированный образ современника - «сына Отечества», открытого идеям Просвещения, мудрого отца и воспитателя достойных наследников. В этом смысле сатирические журналы оказались в авангарде большого утопического проекта русской культуры.

\section{Литература}

1. Гутнер Г. Просвещение как социальный проект // Неприкосновенный запас. 2002. № 5. URL: https://magazines.gorky.media/nz/2002/5 (дата обращения: 143.12.2019).

2. Смесь : новое еженедельное издание. СПб. : Тип. Акад. наук, 1769. 348 с.

3. Всякая всячина. СПб. : Тип. Акад. наук, 1769-1770. 565 с.

4. Бекасова А.В. Отцы, сыновья и публика в России второй половины XVIII века // Новое литературное обозрение. 2012. № 113. С. 99-129.

5. Русская силлабическая поэзия XVII-XVIII вв. М. : Сов. писатель, 1970. 422 с.

6. Лотман Ю.М. Статьи по семиотике культуры и искусства. Проблема знака и знаковой системы и типология русской культуры XI-XIX веков. URL: https:/culture.wikireading.ru/48673 (дата обращения: 14.12.2019).

7. Демин А.С. Писатель и общество в России XVI-XVII веков. М. : Наука, 1985. $341 \mathrm{c.}$

8. Черная Л.А. Русская культура переходного периода от Средневековья к Новому времени. М. : Языки культуры, 1999. 288 с.

9. Трутень : еженедельное издание. СПб. : Тип. Акад. наук, 1769-1770. 
10. Кулакова И.П. «Воздвигнете на небо очи ваши»: взаимодействие философского, научного и художественного дискурсов в российской литературной традиции XVIII века // XVIII век: литература как философия, философия как литература : науч. сб. / под ред. Н.Т. Пахсарьян. М. : Экон-Информ, 2010. С. 29-48.

11. Черепнин Н.П. Императорское воспитательное общество благородных девиц (1764-1914). СПб. : Гос. тип., 1914. Т. 1. 650 с.

12. Яринская А.М. К вопросу о планах создания «новой породы людей» в России в правление Екатерины II // Вестник Томского государственного университета. Сер. Культурология и искусствоведение. 2011. № 1. С. 26-38.

13. Любжин А.И. Краткий очерк истории российского просвещения в XVIII столетии // Лицейское и гимназическое образование. 2007. № 3. С. 37-52.

14. Живописец // Новиков Н. Смеющийся Демокрит. М. : Сов. Россия, 1985. C. $25-170$.

15. Головин В.В. «Полезное с приятным» - первый опыт издания журнала для детей и юношества в России // Клио. 2014. № 7. С. 30-33.

16. Полезное с приятным. СПб. : При Сухопутном шляхетн. кад. корпусе, 1769.

17. Живописец. СПб. : Тип. Акад. наук, 1772-1773.

18. Лихачев Д.С. Избранные работы. Л. : Худож. лит., 1987. Т. 3. 520 с.

19. Адская почта, или Переписки хромоногого беса с кривым : ежемесячное издание. СПб. : Тип. Морского шляхетн. кад. корпуса, 1769-1770.

20. И то и сё. СПб. : Тип. Морского кад. корпуса, 1769.

21. Кусбер Я. Какие знания нужны дворянину в жизни? Провинциальные и столичные воспитательные дискурсы второй половины XVIII и начала XIX века // Дворянство, власть и общество в провинциальной России XVIII века. М. : Новое литературное обозрение, 2012. С. 269-292.

22. Артемьева Т.В. Комментарии // Общественная мысль в России XVIII века / сост. Т.В. Артемьева. М. : Росспэн, 2010. Т. 2. 1063 с.

23. Кулакова И.П. Российское «просвещенное дворянство» в контексте идей Нового времени: специфика форм интеллектуальной деятельности (XVIIIXIX вв.) // Диалог со временем : альманах интеллектуальной истории. М. : Изд-во Моск. ун-та, 2011. С. 90-119.

24. Пустомеля // Новиков Н. Смеющийся Демокрит. М. : Сов. Россия, 1985. C. $170-181$.

25. Солодянкина О.Ю. Иностранные наставники в дворянском домашнем воспитании в России (вторая половина XVIII - первая половина XIX в.) : автореф. дис. ... д-ра ист. наук. М., 2008. 46 с.

26. Вечера : еженедельное издание на 1772 год. СПб. : Тип. Акад. наук, 17721773.

27. Самарин А.Ю. Читатель в России во второй половине XVIII века (по спискам подписчиков). М. : Изд-во МГУП, 2000. 288 с.

28. Шартье Р. Культурные истоки Французской революции. М. : Искусство, $2001.256 \mathrm{c}$.

29. Херасков М.М. Творения : в 14 т. М. : 1796-1803. Ч. 7. 419 с. 
The Plot About the Book and Reading in Satirical Magazines of 1769-1774

Tekst. Kniga. Knigoizdanie - Text. Book. Publishing, 2021, 25, pp. 100-121

DOI: 10.17223/23062061/25/6

Tatyana I. Rozhkova, Nosov Magnitogorsk State Technical University (Magnitogorsk, Russian Federation). E-mail: robin.55@ mail.ru

Keywords: Enlightenment, periodical publications, satire periodicals, books, medieval books, secular books, reading, education, cultural practices.

The interest that modern human science shows in the Enlightenment as time still continues and has become one of the reasons to examine the periodicals of the 1760s and 1770s as part of its complex social and cultural process. Separating a specific cultural practice for analysis allowed concentrating on identifying some anthropological senses in cultural changes and some ways of coping with current conflicts. The author of the article observes how the magazines that are identified as satirical (Truten', Zhivopisets, Vsyakaya Vsyachina, Adskaya Pochta, Smes', and others) make a dialogue between the book and reading. The significance of this topic is the early discussion on the problem of educating the nobility that was held in the society. In the 1760s and 1770s, the topic became popular in a new way because of the ideas of Catherine the Great to educate people "of a new brand". To solve the problem, the government started to reorganize educational institutions whose programs began to include secular science, books and art. However, home schooling remained closed for changes. There, medieval spiritual books still dominated because "aunties"-tutors (so-called "starushki") were afraid of any cultural innovations. The well-known thesis that, in the second part of the century, the authority of medieval texts became weaker is proved by different magazine articles that were based on the daily experience and examinations of contemporaries who were the witnesses of the cultural changes and who had to choose what to read, where and how to teach their children. In publications of different genres, we can notice that the press continued to value the book and reading as a good way to learn and educate. Besides, medieval texts appeared to be something that favored superstitious views on the Universe. In the then contemporary satirical ideas, medieval books marked the changing generation of readers. Some examples of parents' sanctimonious views on religious beliefs, disrespect towards governmental rules, cruel treatment of serfs degraded the value of reading medieval books. On the contrary, positive heroes showed interest in the new secular knowledge and books, tried to become well-read and study foreign languages, to be capable of making a free choice. To bring up such a noble person was only possible if their parents were thoughtful to their children's natural proclivity and to the choice of their tutors, and were sensitive to governmental changes. Generations that could stop reading Old Russian books were changing their reading habits. They became free in choosing books and in reading them critically. The trend to be well-read made reading more dynamic.

\section{References}

1. Gutner, G. (2002) Prosveshchenie kak sotsial'nyy proekt [Enlightenment as a social project]. Neprikosnovennyy zapas. 5. [Online] Available from: https://magazines.gorky. media/nz/2002/5 (Accessed: 14th December 2019). 
2. Anon. (1769) Smes': novoe ezhenedel'noe izdanie [Medley: a new weekly edition]. St. Petersburg: Academy of Sciences.

3. Anon. (1769-1770) Vsyakaya vsyachina [All sorts of things]. St. Petersburg: Academy of Sciences.

4. Bekasova, A.V. (2012) Ottsy, synov'ya i publika v Rossii vtoroy poloviny XVIII veka [Fathers, sons and the public in Russia in the second half of the 18th century]. Novoe literaturnoe obozrenie. 113. pp. 99-129.

5. Adrianova-Peretts, V.P. (1970) Russkaya sillabicheskaya poeziya XVII-XVIII vv. [Russian syllabic poetry of the 17th - 18th centuries]. Moscow: Sovetskiy pisatel'.

6. Lotman, Yu.M. (n.d.) Stat'i po semiotike kul'tury i iskusstva. Problema znaka $i$ znakovoy sistemy i tipologiya russkoy kul'tury XI-XIX vekov [Articles on the semiotics of culture and art. The problem of the sign and sign system and the typology of Russian culture of the 11th -19 th centuries]. [Online] Available from: https://culture.wikireading.ru/48673 (Accessed: 14th December 2019).

7. Demin, A.S. (1985) Pisatel' $i$ obshchestvo v Rossii XVI-XVII vekov [The Writer and Society in Russia in the 16th -17 th centuries]. Moscow: Nauka.

8. Chernaya, L.A. (1999) Russkaya kul'tura perekhodnogo perioda ot Srednevekov'ya $k$ Novomu vremeni [Russian culture of the transition period from the Middle Ages to the New Time]. Moscow: Yazyki kul'tury.

9. Anon. (1769-1770) Truten': ezhenedel'noe izdanie [Lazybones: a weekly edition]. St. Petersburg: Academy of Sciences.

10. Kulakova, I.P. (2010) "Vozdvignete na nebo ochi vashi”: vzaimodeystvie filosofskogo, nauchnogo i khudozhestvennogo diskursov $\mathrm{v}$ rossiyskoy literaturnoy traditsii XVIII veka ["Raise your eyes to heaven": the interaction of philosophical, scientific and artistic discourses in the Russian literary tradition of the 18th century]. In: Pakhsaryan, N.T. (ed.) XVIII vek: literatura kak filosofiya, filosofiya kak literatura [The Eighteenth Century: Literature as Philosophy, Philosophy as Literature]. Moscow: Ekon-Inform. pp. 29-48.

11. Cherepnin, N.P. (1914) Imperatorskoe vospitatel'noe obshchestvo blagorodnykh devits (1764-1914) [Imperial Educational Society for Noble Maidens (1764-1914)]. Vol. 1. St. Petersburg: Gos. tip.

12. Yarinskaya, A.M. (2011) To the question on plans of creation of "new kind of people" in Russia during the reign of Catherine II. Vestnik Tomskogo gosudarstvennogo universiteta. Ser. Kul'turologiya i iskusstvovedenie - Tomsk State University Journal of Cultural Studies and Art History. 1. pp. 26-38. (In Russian).

13. Lyubzhin, A.I. (2007) Kratkiy ocherk istorii rossiyskogo prosveshcheniya v XVIII stoletii [A brief outline of the history of Russian education in the 18th century]. Litseyskoe i gimnazicheskoe obrazovanie. 3. pp. 37-52.

14. Novikov, N. (1985a) Smeyushchiysya Demokrit [Laughing Democritus]. Moscow: Sovetskaya Rossiya. pp. 25-170.

15. Golovin, V.V. (2014) "Poleznoe s priyatnym" - pervyy opyt izdaniya zhurnala dlya detey i yunoshestva v Rossii ["Poleznoe s priyatnym" - the first experience of publishing a magazine for children and youth in Russia]. Klio. 7. pp. 30-33. 
16. Anon. (1769) Poleznoe s priyatnym [Useful with pleasant]. St. Petersburg: The First Cadet Corps.

17. Anon. (1772-1773) Zhivopisets [Artist]. St. Petersburg: Academy of Sciences.

18. Likhachev, D.S. (1987) Izbrannye raboty [Selected works]. Vol. 3. Leningrad: Khudozhestvennaya literatura.

19. Anon. (1769-1770) Adskaya pochta, ili Perepiski khromonogogo besa s krivym: ezhemesyachnoe izdanie [Hellish mail, or Correspondence of a lame imp with a crooked: monthly edition]. St. Petersburg: The Naval Cadet Corps.

20. Anon. (1769) I to $i$ se [This, that, and the other]. St. Petersburg: The Naval Cadet Corps.

21. Kusber, Ya. (2012) Kakie znaniya nuzhny dvoryaninu v zhizni? Provintsial'nye i stolichnye vospitatel'nye diskursy vtoroy poloviny XVIII i nachala XIX veka [What knowledge does a nobleman need in life? Provincial and metropolitan educational discourses of the second half of the 18th and early 19th centuries]. In: Glagoleva, O. \& Shirle, I. (eds) Dvoryanstvo, vlast' $i$ obshchestvo v provintsial'noy Rossii XVIII veka [Nobility, power and society in provincial Russia of the 18th century]. Moscow: Novoe literaturnoe obozrenie. pp. 269-292.

22. Artemieva, T.V. (2010) Kommentarii [Commentary]. In: Artemieva, T.V. (ed.) Obshchestvennaya mysl' $v$ Rossii XVIII veka [Public Thought in Russia in the 18th Century]. Vol. 2. Moscow: Rosspen.

23. Kulakova, I.P. (2011) Rossiyskoe "prosveshchennoe dvoryanstvo" v kontekste idey Novogo vremeni: spetsifika form intellektual'noy deyatel'nosti (XVIII-XIX vv.) [Russian "enlightened nobility" in the context of the ideas of the New Age: the specifics of forms of intellectual activity (the 118th -19th centuries)]. Dialog so vremenem. 36. pp. 90-119.

24. Novikov, N. (1985b) Smeyushchiysya Demokrit [Laughing Democritus]. Moscow: Sovetskaya Rossiya. pp. 170-181.

25. Solodyankina, O.Yu. (2008) Inostrannye nastavniki v dvoryanskom domashnem vospitanii $v$ Rossii (vtoraya polovina XVIII - pervaya polovina XIX v.) [Foreign mentors in noble home education in Russia (the second half of the 18th - first half of the 19th century)]. Abstract of History Dr. Diss. Moscow.

26. Anon. (1772-1773) Vechera: ezhenedel'noe izdanie na 1772 god [Evenings: weekly for 1772]. St. Petersburg: Academy of Sciences.

27. Samarin, A.Yu. (2000) Chitatel'v Rossii vo vtoroy polovine XVIII veka (po spiskam podpischikov) [The Reader in Russia in the second half of the 18th century (according to the list of subscribers)]. Moscow: MSUP.

28. Chartier, R. (2001) Kul'turnye istoki Frantsuzskoy revolyutsii [The Cultural Origins of the French Revolution]. Translated from French. Moscow: Iskusstvo.

29. Kheraskov, M.M. (1796-1803) Tvoreniya: v 14 t. [Works: in 14 vols]. Vol. 7. Moscow: [s.n.]. 